\title{
Quality parameters and thermogravimetric and oxidative profile of Muruci oil (Byrsonima crassifolia L.) obtained by supercritical $\mathrm{CO}_{2}$
}

\author{
Orquidea Vasconcelos SANTOS ${ }^{1 *}$, Nádia Cristina Fernandes CORREA ${ }^{1}$, Raul CARVALHO JUNIOR ${ }^{1}$,
} Carlos Emmerson Ferreira da COSTA ${ }^{1}$, Jaqueline de Fátima Cabral MORAES ${ }^{2}$, Suzana Caetano da Silva LANNES ${ }^{2}$

\begin{abstract}
These researches aimed determine the quality parameters, the nutritional profile, and the thermogravimetric and oxidative behavior of Muruci (Byrsonima crassifolia L.) oil obtained by supercritical $\mathrm{CO}_{2}$ extraction. The results showed an average oil yield of 5.50\%. The acidity and peroxide values show good quality and conservation standards, according to the Brazilian legislation. The fatty acid profile indicates a predominance of unsaturated fatty acids with levels above $60 \%$, highlighting the presence of fatty acids omega- 6 and omega- 9 . The thermogravimetric curves showed oil stability at temperatures around $200{ }^{\circ} \mathrm{C}$ and exothermic peaks characteristic of mass loss close to $250{ }^{\circ} \mathrm{C}$. The data of oxidative induction time determined by the Rancimat method showed thermal oxidative stability of $20.85 \mathrm{~h}$ for the oil obtained. The Fourier transform infrared (FTIR) spectroscopic profile evidenced chemical compounds with predominantly unsaturated structures, confirming its fatty acid profile. Based on the results of the oil analysis, it is possible to recognize the potential of this species in terms of nutritional, functional, and thermo-oxidative stability aspects.
\end{abstract}

Keywords: Muruci oil; thermogravimetry.

Practical Application: From the studies it is recognized the potential of this species in terms of its nutritional, functional, and thermo-oxidative stability aspects, indicating that oil this fruit can be applicator in various industrial segments.

\section{Introduction}

The fruits native the Amazon region have become subject of much research and have attracted the interest of various industrial segments and stimulated the creation of public policies due to their nutritional and functional potential, as reported in previous studies.

Research on weeds in Brazil have been supported by the Ministry of Environment as part of the Conservation and Sustainable Use of Brazilian Biological Diversity program (PROBIO), and it is based on a public consultation process in order to select proposals for the proper identification, prioritization, and dissemination of information about native plants with aggregate potential for commercial purposes. As a result, a list of species of high potential and economic value, among which is muruci (Brasil, 2016) have been compiled.

Muruci, the fruit of Murucizeiro (Byrsonima crassifolia L.), belongs to the family Malpighiacea, which is widely distributed in the Amazon region, mainly in the North, Northeast, and Midwest regions. It can also be found in other countries that border Brazil Amazon and in some countries in Central America and the Caribbean (Rezende \& Fraga, 2003).

Muruci is a drupoid fruit, which is round or oblong in shape and has intense aroma and peculiar flavor. Its biometric characteristics such as size, weight, and diameter, may vary. These variations are due to genetic, edaphoclimatic, and instrumental factors related to the measurement of these parameters. Its peak production in the Microregion of Belém, state of Pará (PA), occurs between October and January, and it may be produced up to mid-March and April in some areas (Carvalho et al., 2007).

The nutritional composition and functional aspects of this fruit have been little explored. Evidences from research so far have been scanty, but values of $4.74 \%$ lipid, $5.45 \%$ protein, $4.89 \%$ sugars, and $14.91 \%$ fiber, high water content (around 70\%), and significant amount of vitamins and minerals have been reported. It is considered a low-calorie fruit (Cruz, 1998).

The nutritional composition of this fruit has fostered research focusing on its functionality, especially using appropriate technologies for separation and/or isolation of its main compounds, either in terms of lipid, protein, and fibers or bioactive compounds such as carotenoids and phytosterols, among others (Siguemoto, 2013).

The action of bioactive compounds has become a major focus of research interest, especially as a source of antioxidant and therapeutic resource, due to their action on compounds harmful to the cellular matrix, as well as their healing effects and pro- and anti-inflammatory properties. As a result, some studies have reported that muruci has antioxidant compounds, 
including phenolic compounds, carotenoids, and ascorbic acid (Almeida et al., 2011; Souza et al., 2012; Siguemoto, 2013).

Its nutritional and functional quality is a distinctive characteristic that have been the subject of much research. Among its macronutrients, lipids stand out, mainly due to their nutritional-energetic and functional-bioactive aspects based on their caloric value, which is higher than that of the other macronutrients (9 kcal/g of oxidized material), and on its fatty acid profile, with special emphasis on the presence of unsaturated fatty acids, and their pro- and anti-inflammatory actions (Siguemoto, 2013).

When isolated, these lipids can have different degrees of stability, and they are usually sensitive to different environmental conditions or to the composition of the raw materials, which can change their nutritional and functional qualities. External factors, such as autoxidation, thermal oxidation (induced by temperature), and photo-oxidation (induced by light) can lead to major changes in the chemical composition of the unsaturated bonds within the carbon chains of these oils, especially in the presence of oxygen in contact with the unsaturated fatty acids, which induces a reaction converting the oxygen to its excited singlet state, thus reducing the stability of the material (Santos et al., 2013a, b).

The determination of the oxidative stability of oils can be performed by measuring the oxidative stability Index (OSI), which is an automated analysis by instruments that simulate events based on the formation of oxidation compounds under specific atmospheres, usually at high temperatures, determining the induction time of the oil. Oxidative stability can also be assessed by laboratory analyses, including sensory analysis, and by monitoring the peroxide value, measuring conjugated dienes, anisidine, and carbonyl values, and monitoring spectroscopic changes by resonance, infrared, fluorescence, and luminescence techniques among others (Tan et al., 2002; Masuchi et al., 2008).

Advances in the research on fruits' functional and bioactive aspects require compound isolation and the assessment of its quality and stability due to the changes it underwent and aiming at adding value and its application in many sectors of the food, pharmaceutical, cosmetic, and skin care industries among others.

In this perspective the application of supercritical fluid is a viable alternative to conventional methods used for the extraction of various types of vegetable oils preserving its richness in essential fatty acids. Applying a supercritical fluid as an extracting solvent, especially carbon dioxide $\left(\mathrm{CO}_{2}\right)$, in the supercritical fluid extraction has advantages due to its non-corrosive nature, its non-toxicity and non-flammability properties, and to the fact that it is easily removed from the extracted product. The operation conditions can be controlled reducing the costs with compression (Temelli, 2009; Sovová et al., 2010; Rubio-Rodríguez et al., 2008; Sovová, 2012; Santos et al., 2012).

Therefore, the major objective of this research was to assess the quality parameters, the fatty acid profile, and the thermogravimetric and oxidative behavior of Muruci oil obtained by supercritical $\mathrm{CO}_{2}$ extraction.

\section{Materials and methods}

\subsection{Muruci}

To obtain muruci pulp (Byrsonima crassifolia L.) for the analyses, $10 \mathrm{~kg}$ of this fruit (crop January 2014) were purchased from the Fresh Fruit and Vegetable Supply Center of Pará (CEASA-PA). The fruits were grown in the municipality of Vigia, PA, registered in the João Pires Murça (MG) Herbarium (part of the Emilio Goeldi museum, MG), also known as "herbárium Amazanicum Musei paraenses” under the \# MG 66803.

\subsection{Muruci pulp extraction}

The fruits were selected, washed, disinfected with a sodium hypochlorite solution (50 ppm), and then rinsed with tap water to remove the sanitizing solution. Next, the fruits were pulped, and the pulp obtained was fractionated and packaged in bags of low density polyethylene and stored under freezing temperature $\left(-7^{\circ} \mathrm{C}\right)$ until the completion of successive extractions and analyses.

\subsection{Pre-treatment of samples}

The preparation of the samples used in the extraction steps included drying the muruci pulp in an air circulation oven (FABBE model 170), with recirculating air at $60^{\circ} \mathrm{C}$ for 24 hours and reduced water content to an average of $6 \%$, followed by the standardization of the material particles to be used in the extractions using a Magnetic Sieve Shaker $\left(\right.$ BERTEL $^{\circledR}$, model 1713) standardized in Granulotest sieves (Mesh No. 28, 35, 42, 48, and 65) of $1.20 \mathrm{~mm}$ average particle diameter, which represented $1 / 3$ of the largest proportions obtained at concentrations of retained mass in the sieves 35,42 , and 48 , respectively, according to the methodology of the Instituto Adolfo Lutz (1985).

The material retained on each sieve was weighed on an analytical balance (QUIMIS). The crushed and sieved particles were vacuum packed and stored in a chest freezer (Consul) at a temperature below $-10{ }^{\circ} \mathrm{C}$. The average particle diameter was calculated using Equation 1, according to the model recommended by American Society of Agricultural Engineers (1998).

$d_{m g}=\left[\frac{\sum_{i=1}^{n}=\left(w_{i} \log \bar{d}_{i}\right)}{\sum_{i=1}^{n} w}\right]$

where: $\bar{d}_{i=}\left(d_{i} d_{i+1}\right)^{0.5}$;

$\mathrm{d}_{\mathrm{i}}=$ nominal opening of the $\mathrm{i}^{\text {th }}$ sieve $(\mathrm{mm})$;

$\mathrm{d}_{\mathrm{i}+1}=$ nominal sieve opening larger than the $\mathrm{i}^{\text {th }}$ sieve $(\mathrm{mm})$;

$\mathrm{w}_{\mathrm{i}}=$ weight of material retained on the $\mathrm{i}^{\text {th }}$ sieve.

\subsection{Extraction of Muruci oil}

Extractions of the muruci oils were performed on the Spe-ed ${ }^{\mathrm{TM}}$ SFE (Allentown, PA, USA) model 7071 from Applied Separations, with Schulz compressor model CSA 7.8 coupled, with internal volume of 19.71 from Schulz S/A (Joinville, SC, Brazil), The supercritical fluid extractor unit uses carbon dioxide P-4574 $\left(\mathrm{CO}_{2}\right)$, 99.9\% purity, (Industry White Martins, 
Belém-PA) from a cylindrical reservoir with a capacity of $30 \mathrm{~kg}$ at pressure of 70 bar. After defining the optimum parameters of temperature and pressure that resulted in the best yield, exhaustive extractions were performed in order to obtain material for subsequent analyses. Polyscience recircularizer F08400796 (Nilles, Illinois, USA) and $\mathrm{CO}_{2}$ output meter Alicat Scientific M 5SLPM (Tucson, AZ, USA). The extraction was done in the Laboratory of Thermal Separations, Federal University of Pará (THERMTEK/UFPA).

The instrument cluster constituting the Applied Separation system was connected to the electrical supply. The inlet, outlet and vent valves remained closed and the micrometric valves partially closed. Subsequently, the extraction cell (column) was packed with lyophilized muruci pulp. A small amount of cotton was inserted in the column (at both internal ends) in order to avoid the entry of particulates from the raw material into the capillary ducts of the equipment, which could cause obstruction of the passage of $\mathrm{CO}_{2}$ and oil. Glass beads were also inserted, which allowed the complete internal filling of the column. After the steps described, the column was inserted into the extraction system.

The supercritical fluid extractor unit uses carbon dioxide P-4574 $\left(\mathrm{CO}_{2}\right), 99.9 \%$ purity, (Industry White Martins, Belém-PA) from a cylindrical reservoir with a capacity of $30 \mathrm{~kg}$ at pressure of 70 bar. After defining the optimum parameters of temperature and pressure that resulted in the best yield, exhaustive extractions were performed in order to obtain material for subsequent analyses.

\section{Physical and chemical characterization of the oil}

The extracted oil was characterized by the following analyses: Acid Value (AOCS Cd 3d-63), Peroxide Value (AOCS Cd 8-53), Saponification Value (AOCS Cd 3-25).

\section{Fatty acid profile}

The determination and quantification of fatty acids in the oil was carried out by gas chromatography (GC), according to the methodology of the Commission des Communautés Européennes (1977). Triacylglycerols were converted to methyl esters of fatty acid using the AOCS CE 266 method (American Oil Chemistry Society, 1998).

The analysis of fatty acid composition by gas chromatography was performed on a VARIAN CP 3800 Autoinjector chromatograph equipped with a flame ionization detector (FID) and a capillary column CP MAX 52 CB (30 m length, $0.32 \mathrm{~mm}$ internal diameter, and $0.25 \mu \mathrm{m}$ of film). Helium gas was used as the mobile phase at a rate of $1.0 \mathrm{~mL} / \mathrm{min}$. The temperature program was $\mathrm{T}_{1}$ at $80{ }^{\circ} \mathrm{C}$ for 2 minutes, $\mathrm{R}_{1}$ at $10^{\circ} \mathrm{C} / \mathrm{min}, \mathrm{T}_{2}$ at $180{ }^{\circ} \mathrm{C}$ for 1 minute, $\mathrm{R}_{2}$ at $10^{\circ} \mathrm{C} / \mathrm{min}$, and $\mathrm{T}_{3}$ at $250^{\circ} \mathrm{C}$ for 5 minutes.

The fatty acids were identified by comparison with methyl ester standards (Aldrich Chemical Company, USA). Quantification of fatty acids resulted in normalizing the peak area using W.S Star 6.0 software (Varian USA).
Thermogravimetric and Differential Thermal Analyzes (TG-DTA)

These analyses were performed on a Shimadzu thermobalance (DTG-60 H) under the following parameters: air flow of $60 \mathrm{~mL} / \mathrm{min}$, heating ramp rate of $10^{\circ} \mathrm{C} /$ minute, and temperature range from 20 to $600{ }^{\circ} \mathrm{C}$ using aluminum crucibles and mass $5 \pm 0.5 \mathrm{mg}$.

\section{Differential Scanning Calorimetry (DSC)}

The DSC analyses were performed on a Shimadzu DSC-60A (induced oxidation) under the following parameters: oxygen flow rate: $50 \mathrm{~mL} /$ minute, heating ramp rate of $10{ }^{\circ} \mathrm{C}$, and temperature of 100,120 , and $140^{\circ} \mathrm{C}$ using aluminum crucibles and mass $5 \pm 0.5 \mathrm{mg}$.

\section{Oxidative stability analysis: Rancimat method}

The analysis of the oxidation induction period assessed by Rancimat was performed using a Rancimat test equipment (Metron 743) under the following parameters: temperature of $100^{\circ} \mathrm{C}$, air flow of $10 \mathrm{ml} / \mathrm{h}$, and an oil sample of $5 \mathrm{~g}$ (American Oil Chemistry Society, 1996).

\subsection{Infrared absorption spectroscopy}

Infrared absorption spectroscopy was performed on an IR 100 spectrophotometer (Thermo Electron Corporation) with $2 \mathrm{~cm}^{-1}$ resolution and 64 scans and optical range of $4000-400 \mathrm{~cm}^{-1}$.

\section{Results and discussion}

\subsection{Physicochemical characteristics of Muruci oil}

The yield of the oil extracted from the peel and pulp of muruci fruit had an average value of $5.50 \%$ (dry basis). The physicochemical parameters are shown in Table 1.

The data presented in Table 1 show one of the key aspects of the oil, the acidity value with a mean value of $1.2 \mathrm{mg} \mathrm{KOH} \mathrm{g}^{-1}$. This a parameter is related to the nature and quality of the raw material; it can reveal the state of conservation of the oil and represents its compliance with one of the most important quality standards established by the Brazilian legislation for oils and fats (Brasil, 2005).

This parameter is within the limits established by Codex Alimentarius and the National Health Surveillance Agency (ANVISA), which established maximum acidity value of $4.0 \mathrm{mg} \mathrm{KOH} \mathrm{g}^{-1}$ for crude and unrefined oils (Food and Agriculture Organization of the United Nations, 2003; Brasil, 2005).

Table 1. Physicochemical characteristics of Muruci oil.

\begin{tabular}{cc}
\hline Analyses & Supercritical $\mathrm{CO}_{2}$ Extraction \\
\hline Acidity value $\left(\mathrm{mg} \mathrm{KOH} \mathrm{g}^{-1}\right)$ & $1.2 \pm 0.7$ \\
Peroxide value $\left(\mathrm{m} \mathrm{Eq} \mathrm{kg}^{-1}\right)$ & $1.2 \pm 0.5$ \\
Saponification value & $188.5 \pm 0.2$
\end{tabular}

Data express mean \pm standard deviation of triplicates $(n=3)$. 
The second quality parameter assessed was the peroxide value with an average value of $1.2 \pm 0.5 \mathrm{~m} \mathrm{Eq} \mathrm{kg}^{-1}$. The acidity and peroxide values are directly related to the quality of the oils and are the only physicochemical parameters established by ANVISA to define oil quality, with maximum values in the range of $15 \mathrm{~m} \mathrm{Eq} \mathrm{kg}^{-1}$ oil and $4.0 \mathrm{mg} \mathrm{KOH} \mathrm{g}^{-1}$ for the peroxide value and acidity value, respectively (Brasil, 2005).

Another parameter evaluated was the saponification value, with an average of $188.5 \mathrm{mg} \mathrm{KOH} \mathrm{g}^{-1}$ value close to that found for Santos et al. (2017) of $207.68 \mathrm{mg} \mathrm{KOH} \mathrm{g}^{-1}$. According to the authors this index is inversely proportional to the average molecular weight of the fat and is used to observe the size of the fatty acid chain, Moreover this is an important parameter in oil and fat evaluations since it indicates the presence of high molecular weight fatty acids. Saponification value can be considered as being inversely proportional to the mean molecular weight of the fatty acids present in triacylglycerols (Instituto Adolfo Lutz, 1985). This index may exhibit different standards influenced by factors such as the levels of free fatty acids, degree of oxidation, heat treatment, etc. (Instituto Adolfo Lutz, 1985).

\section{Fatty acid profile}

The analysis of the composition and quality of fatty acids and the assessment of the essentiality of the functional properties of muruci oil are shown in Table 2.

The results of the fatty acid profile of muruci oil showed the predominance of oleic and linoleic unsaturated fatty acids, with averages values close to $44 \%$ and $16 \%$, respectively, which is directly related to their degree of functionality in the human body since, in addition to meeting nutritional needs, they modulate the immune system (Zivkovic et al., 2011).

The predominance of unsaturated fatty acids in this fruit makes it a functional food based on the major constituents of its lipid profile, such as oleic ( $\omega-9)$ and linoleic ( $\omega-6)$ acids. The oleic acid content in the muruci oil was higher than the value found in the sunflower oil, 21.6\% (Nimet, 2011), and Brazil nut oil, 31.24\% (Santos et al., 2012). Due to its high content of oleic acid, muruci oil can be classified as a predominantly monounsaturated oil.

Table 3 shows the ratio of saturated and unsaturated fatty acids of muruci oil compared with those of other vegetable oils from the Amazon.

The ratio between unsaturated and saturated fatty acids in the muruci oil was lower than that of other oils from Amazonian oleaginous species. Showing that this oil is rich in saturated fatty acids, nutritionally they become undesirable, since high levels of saturated fatty acids are considered to have influence in increasing the concentration of low density lipoproteins, affecting the ratio of High Density Lipoproteins (LDL) to Low Density Lipoproteins (HDL) (Zambiazi et al., 2007; Kostik et al., 2013).

The determination of the fatty acid content $e$ as well as the ratio between oleic and linoleic fatty acids is important parameter for determination of nutritional value of the oils, furthermore increase in this ratio reduced levels of isoprostanes, biomarkers of oxidative stress (Høstmark \& Haug, 2013; Kostik et al., 2013).
Table 2. Fatty acid profile of muruci oil.

\begin{tabular}{ccc}
\hline Chain & Fatty Acids & $\begin{array}{c}\text { Supercritical } \mathrm{CO}_{2} \\
\text { Extraction }\end{array}$ \\
\hline C8:0 & Caprylic & 1.8 \\
C10:0 & Capryc & 0.1 \\
C12:0 & Lauric & 0.3 \\
C14:0 & Myristic & 0.4 \\
C16:0 & Palmitic & 32.9 \\
C16:1 & Palmitoleic & 1.9 \\
C17:0 & Heptadecanoic & 0.0 \\
C18:0 & Stearic & 1.9 \\
C18:1 $(\omega-9)$ & Oleic & 44.4 \\
C18:2 $(\omega-6)$ & Linoleic & 16.3 \\
C18:3( $\omega-3)$ & Linolenic & 0.0 \\
Saturated & - & 37.4 \\
Unsaturated & - & 62.6 \\
Total & - & 100.00 \\
\hline
\end{tabular}

Table 3. Ratio of saturated and unsaturated fatty acids in oleaginous species from the Amazon region.

\begin{tabular}{ccc}
\hline Vegetable Oils & $\begin{array}{c}\text { unsaturated/Saturated } \\
\text { fatty acid ratio }\end{array}$ & $\begin{array}{c}\text { Oleic /Linoleic fatty } \\
\text { acid ratio }\end{array}$ \\
\hline Brazil nut $^{1}$ & 2.90 & 0.97 \\
Açaí $^{2}$ & 2.72 & 3.39 \\
Tucuma $^{3}$ & 3.48 & 17.77 \\
Buriti $^{4}$ & 4.78 & 28.54 \\
Muruci & 1.67 & 2.72 \\
\hline
\end{tabular}

${ }^{1}$ Santos et al. (2013a); ${ }^{2}$ Batista et al. (2016); ${ }^{3}$ Costa et al. (2016); ${ }^{4}$ Cunha et al. (2012)

A high oleic to linoleic $(\mathrm{O} / \mathrm{L})$ acid ratio results in an increased shelf life. Thus the high $\mathrm{O} / \mathrm{L}$ trait is desired by the oils industry because it confers high oxidative stability to the oil (Chamberlin et al., 2011, 2014; Chu et al., 2011).

\section{Thermogravimetric and differential thermal analyses}

The nutritional and functional qualities of the fatty acid profile of the muruci oil are based primarily on their degree of unsaturation. However, this structure means instability in the presence of certain elements that can contribute to oxidation; temperature and oxygen are the most deleterious agents of these oils, as can be seen in Figure 1.

The thermogravimetric profile of the muruci oil shows its behavior toward the gradual temperature increase and the air atmosphere, especially by the action of the oxygen present.

Thermogravimetric and differential thermal analyses (TGA/DTA) indicate oil stability up to $200^{\circ} \mathrm{C}$ with great mass loss around $250{ }^{\circ} \mathrm{C}$; mass loss increases with the increase in temperature, which is higher than the maximum operating temperature value normally used in most activities involved in food preparation.

The remaining variation in mass loss patterns at temperatures higher than $250{ }^{\circ} \mathrm{C}$ lead to successive degradation of the sample and severe decay and mass loss until complete sample decomposition at about $500{ }^{\circ} \mathrm{C}$. 


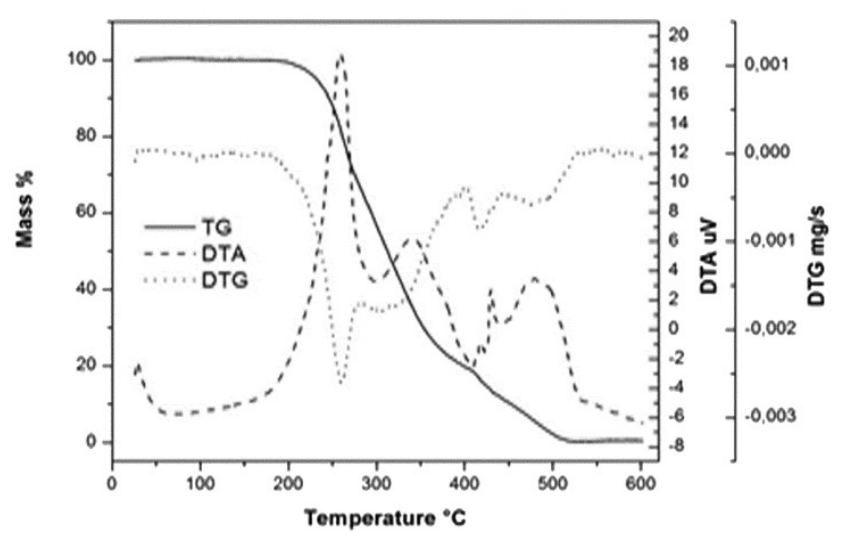

Figure 1. Thermogravimetric behavior of muruci oil.

This event can best be visualized by the decline to the baseline, as shown by the DTG curve, confirming the most severe sample decomposition (mass loss) at temperatures around $250{ }^{\circ} \mathrm{C}$ and maintaining a nonlinear pattern of behavior changes with apparent mass gain fluctuations, which was possibly caused by oxidation due to the presence of oxygen in the analysis atmosphere and the activity of antioxidant compounds such as carotenoids present in this oil, as shown in the graph, and resisting the action of elements that can contribute to oxidation, such as temperature and the air atmosphere, used in this analysis.

Regarding the thermal behavior exhibited by the DTA curve, it is possible to observe three successive events. The first two peaks are in the region with the highest decomposition of the material, between $250{ }^{\circ} \mathrm{C}$ and $300{ }^{\circ} \mathrm{C}$, on average, followed by other events of lesser intensity until the last relevant event, around $500{ }^{\circ} \mathrm{C}$, indicating predominance of exothermic behavior caused by the energy release from the decomposition of the material.

These exothermic behaviors result from the predominance of triglycerides in the carbon chain of this oil, which, during the heating process, release volatile compounds that are responsible for energy release. Such behavior also results from the fatty acid profile of this oil, with predominance of unsaturated fatty acids, which are the first to be decomposed due to their oxidative and thermal instability (Santos et al., 2013a).

The behavior exhibited by the TG, DTG, and DTA curves indicates changes in the muruci oil extracted by supercritical $\mathrm{CO}_{2}$ when subjected to temperature and air atmosphere changes. The results show the effects of the vegetable oil oxidation expressed as exothermic reactions, similar to the behaviors reported by Corso (2008) in studies on the extraction of oil from sesame seeds, using n-propane solvents and pressurized carbon dioxide, and extraction of Brazil nut oil using different methods of extraction (Santos et al., 2013b).

When analyzed for the comparison with the accelerated stability, the DSC curve (Figure 2), shows a major oxidation peak for this oil at temperature around $430{ }^{\circ} \mathrm{C}$. This behavior confirms the profile of the TG and DTA curves, when they are compared since at this temperature there is a great mass loss and release of significant amount of energy resulting from the

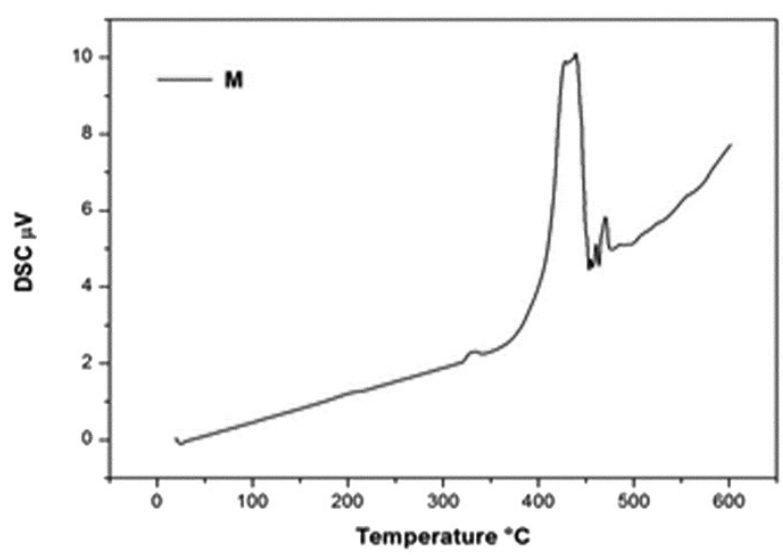

Figure 2. Differential scanning calorimetry (DSC).

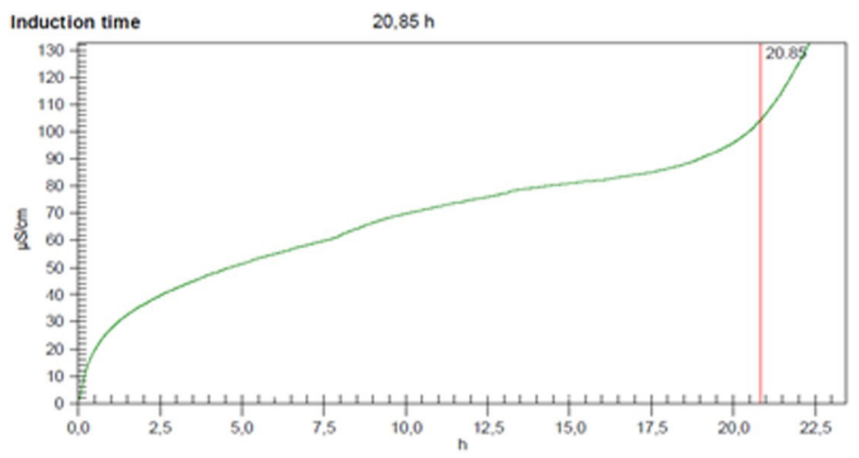

Figure 3. Oxidative induction time.

almost complete decomposition of lipids due to the action of temperature and the oxidizing atmosphere.

Evaluating the oxidative stability using the Rancimat method (Figure 3), the resistance of this raw material to the parameters used in this analysis $\left(100^{\circ} \mathrm{C}\right.$ in air atmosphere can be observed, with a thermal oxidative stability of $20.85 \mathrm{~h}$. This is a highly relevant fact since this method simulates the activity of the elements that contribute to oxidation although it does not necessarily represent the same real storage conditions because the mechanisms of oxidation induction are different at high temperatures and consequently do not reflect the real stability or quality of the oils under normal conditions of use. However, these data obtained by an official analysis method allow for quicker assessment of the oxidative stability of oils, thus making it more practical and convenient for routine laboratory tests.

The comparison of the DSC and Rancimat analysis methods to determine the stability and oxidative induction time of several commercial vegetable oils has shown good correlation between these methods (Kaijser et al., 2000; Souza et al., 2007; Masuchi et al., 2008). Rancimat is the most widely used method for routine analysis in the manufacture of oils and fats because it is simple, it does not include toxic substances, and it is not time consuming or costly (Pardauil et al., 2011; Santos et al., 2013b). The chemical composition of muruci oil was also assessed (Figure 4) by Fourier Transform Infrared Spectroscopy (FTIR). 


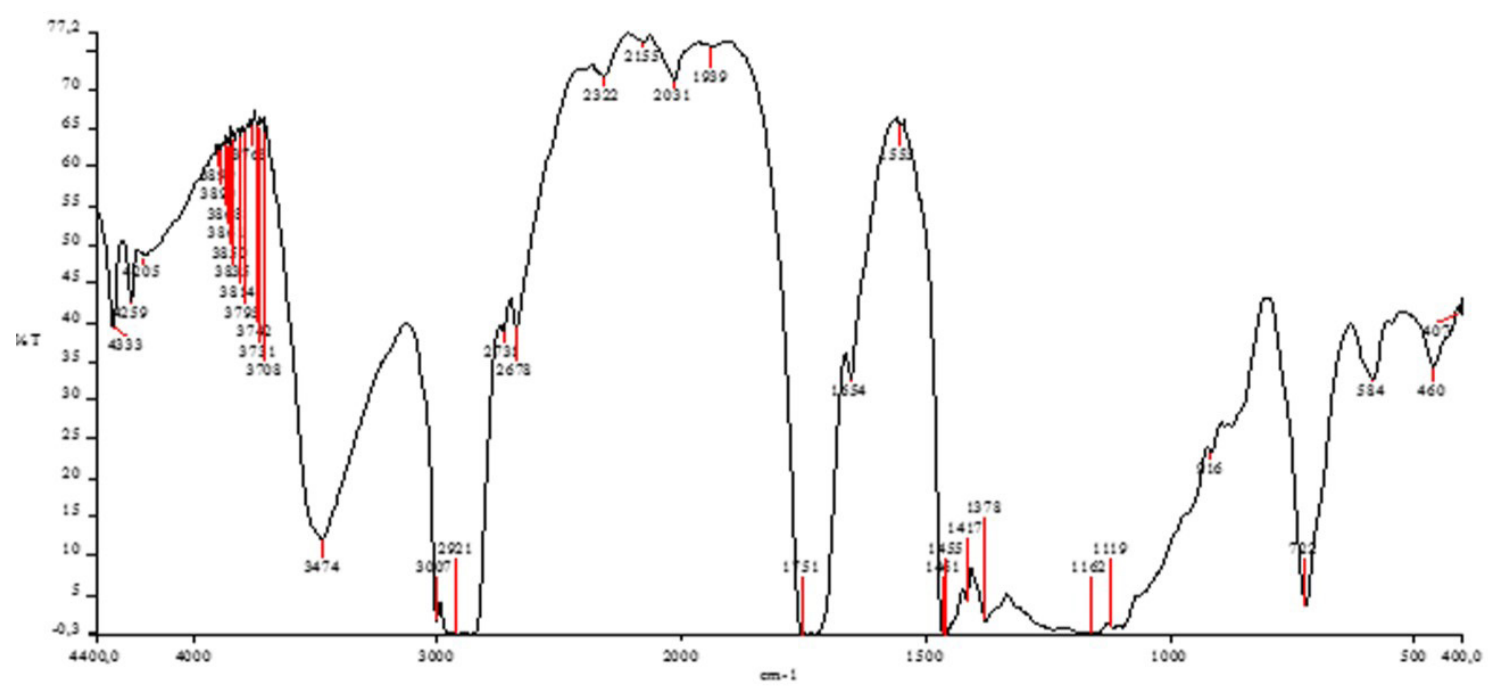

Figure 4. Spectroscopic profile of muruci oil.

Spectroscopic analysis was applied aiming to determine the state of conservation of this oil considering the extraction method used. There are no peaks indicating significant oxidation reactions in the vibrational spectra of this oil; these reactions can be evidenced by the presence of bands around $854 \mathrm{~cm}^{-1}$, assigned to the vibration of - $\mathrm{CH} 2$ groups; bands at $900 \mathrm{~cm}^{-1}$, assigned to the presence of double bonds and their cis-trans isomerization reactions; and the bands over the range of $3000 \mathrm{~cm}^{-1}$ are also characteristic of oxidative processes (Constantino, 2009; Fonseca, 2009; Teles, 2009).

The presence of bands with higher intensity and frequency between 1900 and $2300 \mathrm{~cm}-1$ shows the significant presence of unsaturated compounds in the carbon chain of this material, confirming the predominance of unsaturated fatty acids, as detected in the fatty acid profile analysis, and the protection provided by the supercritical $\mathrm{CO}_{2}$ extraction method against elements that cause degradation preventing oxidation and the presence of compounds with vibrational frequency characteristic oil, which can indicate a possible oxidation state or oxidation process.

\section{Final considerations}

The average oil yield was $5.50 \%$, indicating a high-quality material, expressed by the acidity and peroxide values based on the values established by the Brazilian legislation.

The nutritional quality of this material was expressed by the predominance of unsaturated fatty acids, highlighting the presence of omega- 6 and omega- 9 fatty acids.

The thermogravimetric curves showed oil stability at temperatures around $200^{\circ} \mathrm{C}$, with exothermic peaks characteristic of mass loss close to $250^{\circ} \mathrm{C}$.

The data of oxidative induction time showed a thermal oxidative stability of $20.85 \mathrm{~h}$.
The Fourier transform infrared (FTIR) spectroscopic profile evidenced chemical compounds with predominantly unsaturated structures, confirming its fatty acid profile.

Based on the analytical and instrumental results obtained, it is possible to recognize the potential of this species in terms of its nutritional, functional, and thermo-oxidative stability aspects, indicating that this fruit can be used in various industrial segments.

\section{References}

Almeida, M. M. B., Sousa, P. H. M., Arriaga, A. M. C., Prado, G. M., Magalhães, C. E. C., Maia, G. A., \& Lemos, T. L. G. (2011). Bioactive compounds and antioxidant activity of fresh exotic fruits from northeastern Brazil. Food Research International, 44(7), 2155-2159. http://dx.doi.org/10.1016/j.foodres.2011.03.051.

American Oil Chemistry Society - AOCS. (1996). Official and tentatives methods of American Oil Chemistry Society. New York: AOCS.

American Oil Chemistry Society - AOCS. (1998). Official methods and recommended practices of the American Oil Chemistry Society (5th ed.). Champaign: AOCS.

American Society of Agricultural Engineers - ASAE. (1998). Standards, engineering practices and data developed and adopted by the American Society of Agricultural Engineers. Michigan: ASAE.

Batista, C. C. R., Oliveira, M. S., Araújo, M. E., Rodrigues, A. M. C., Botelho, J. R. S., \& Souza, A. P. S., Fo. (2016). Supercritical $\mathrm{CO}_{2}$ extraction of açaí (Euterpe oleracea) berry oil: global yield, fatty acids, allelopathic activities, and determination of phenolicand anthocyanins total compounds in the residual pulp. The Journal of Supercritical Fluids, 107, 364-369. http://dx.doi.org/10.1016/j. supflu.2015.10.006.

Brasil, Ministério da Saúde. (2005, September 23). Regulamento técnico para óleos vegetais, gorduras vegetais e creme vegetal (Resolução RDC $\mathrm{n}^{\circ} 270$, de 22 de setembro de 2005). Diário Oficial [da] República Federativa do Brasil. 
Brasil, Ministério do Meio Ambiente. (2016). Espécies nativas da flora brasileira de valor econômico atual ou potencial: plantas para o futuro: região centro-oeste. Brasília.

Carvalho, J. E. U., Nascimento, W. M. O., \& Müller, C. H. (2007). Propagação do Murucizeiro (Byrsonima crassifolia (L.) Rich.). In J. E. U. Carvalho, W. M. O. Nascimento \& C. H. Müller. Produção de mudas de espécies frutíferas nativas da Amazônia (pp. 87-99). Fortaleza: Instituto Frutal.

Chamberlin, K. D., Barkley, N. A., Tillman, B. L., Dillwith, J. W., Madden, R., Payton, M. E., \& Bennett, R. S. (2014). A comparison of methods used to determine the oleic/linoleic acid ratio in cultivated peanut (Arachis hypogaea L.). Agricultural Sciences, 5(03), 227-237. http:// dx.doi.org/10.4236/as.2014.53026.

Chamberlin, K. D., Melouk, H. A., Madden, R., Dillwith, J. W., Bannore, Y., El Rassi, Z., \& Payton, M. (2011). Determining the oleic/linoleic acid ratio in a single peanut seed: a comparison of two methods. Peanut Science, 38(2), 78-84. http://dx.doi.org/10.3146/PS11-3.1.

Chu, Y., Wu, C. L., Holbrook, C. C., Tillman, B. L., Person, G., \& OziasAkins, P. (2011). Marker-assisted selection to pyramid nematode resistance and the high oleic trait in peanut. The Plant Genome, 4(2), 110-117. http://dx.doi.org/10.3835/plantgenome2011.01.0001.

Commission des Communautés Européennes. (1977). Méthode d'analyse communautaire à utiliser pour la determination de la teneur en acid érucique, en ce qui concerne les graines prises en charge par les organismes d'intervention (Eur. L12:12-18). Bruxelles.

Constantino, R. (2009). Espectroscopia de lente térmica: um novo método para a avaliação da oxidação e da eficiência da reação de transesterificação durante a produção de biodiesel (Tese de doutorado). Universidade Estadual de Maringá, Maringá.

Corso, M. P. (2008). Estudo da extração de óleo de sementes de gergelim (Sesamun indicum l.) empregando os solventes dióxido de carbono supercrítico e n-propano pressurizado (Dissertação de mestrado). Universidade Estadual do Oeste do Paraná, Toledo.

Costa, B. E. T., Santos, O. V., Corrêa, N. C. F., \& França, L. F. (2016). Comparative study on the quality of oil extracted from two tucumã varieties using supercritical carbon dioxide. Food Science and Technology, 36(2), 322-328. http://dx.doi.org/10.1590/1678-457X.0094.

Cruz, P. E. N. (1998). Caracterização química e nutricional de algumas frutas do estado do maranhão (Tese de doutorado). Universidade Federal do Maranhão, São Luís.

Cunha, M. A. E., Neves, R. F., Souza, J. N. S., França, L. F., Araújo, M. E., Brunner, G., \& Machado, N. T. (2012). Supercritical adsorption of buriti oil (Mauritia flexuosa Mart.) in $\gamma$-alumina: a methodology for the enriching of anti-oxidants. The Journal of Supercritical Fluids, 66, 181-191. http://dx.doi.org/10.1016/j.supflu.2011.10.021.

Fonseca, M. M. (2009). Estudo do óleo de linhaça natural e envelhecido artificialmente em sistemas contendo óxido de zinco e dióxido de titânio (Tese de doutorado). Universidade Federal de Minas GeraisMG, Belo Horizonte.

Food and Agriculture Organization of the United Nations - FAO. Codex Alimentarius Commission Joint FAO/WHO Food Standards Programme. (2003). Codex Committee on food additives and contaminants. Rome: FAO. Retrieved from http://www.codexalimentarius.org/input/ download/report/47/fa03_01e.pdf

Høstmark, A. T., \& Haug, A. (2013). Percentage oleic acid is inversely related to percentage arachidonic acid in total lipids of rat sérum. Lipids in Health and Disease, 12, 40. PMid:23521743.

Instituto Adolfo Lutz - IAL. (1985). Normas analíticas do Instituto Adolfo Lutz: métodos químicos e físicos para análise de alimentos (3. ed., Vol. 1, 533 p.). São Paulo: O Instituto.
Kaijser, A., Dutta, P., \& Savage, G. (2000). Oxidative stability and lipid composition of macadamia nuts grown in New Zealand. Food Chemistry, 71(1), 67-70. http://dx.doi.org/10.1016/S0308-8146(00)00132-1.

Kostik, V., Memeti, S., \& Bauer, B. (2013). Fatty acid composition of edible oils and fats. Journal of Hygienic Engineering and Design, 4, 112-116.

Masuchi, M. H., Celeghini, R. M. S., Gonçalves, L. A. G., \& Grimaldi, R. (2008). Quantificação de TBHQ (terc butil hidroquinona) e avaliação da estabilidade oxidativa em óleos de girassol comerciais. Química Nova, 31(5), 1053-1057. http://dx.doi.org/10.1590/S010040422008000500020 .

Nimet, G. (2011). Avaliação dos solventes dióxido de carbono supercrítico e propano subcrítico na extração do óleo de girassol (Dissertação de mestrado). Universidade Estadual do Oeste do Paraná, Toledo.

Pardauil, J. J. R., Souza, L. K. C., Molfetta, F. A., Zamian, J. R., Rocha, G. N., Fo., \& Costa, C. E. F. (2011). Determination of the oxidative stability by DSC of vegetable oils from the Amazonian área. Bioresource Technology, 102(10), 5873-5877. http://dx.doi.org/10.1016/j. biortech.2011.02.022. PMid:21411317.

Rezende, C. M., \& Fraga, S. R. G. (2003). Chemical and aroma determination of the pulp and seeds of murici (Byrsonima crassifolia L.). Journal of the Brazilian Chemical Society, 14(3), 425-428. http:// dx.doi.org/10.1590/S0103-50532003000300014.

Rubio-Rodríguez, N., De Diego, S. M., Beltran, S., Jaime, I., Sanz, M. T., \& Rovira, J. (2008). Supercritical fluid extraction of the $\mathrm{x}-3$ rich oil contained in hake (Merluccius capensis-Merluccius paradoxus) by-products: study of the influence of process parameters on the extraction yield and oil quality. The Journal of Supercritical Fluids, 47(2), 215-226. http://dx.doi.org/10.1016/j.supflu.2008.07.007.

Santos, O. V., Corrêa, N. C. F., Carvalho, R. N. Jr., Costa, C. E. F., França, L. F., \& Lannes, S. C. S. (2013a). Comparative parameters of the nutritional contribution and functional claims of Brazil nut kerners, oil and defatted cake. Food Research International, 51(2), 841-847. http://dx.doi.org/10.1016/j.foodres.2013.01.054.

Santos, O. V., Corrêa, N. C. F., Carvalho, R. N. Jr., Costa, C. E. F., \& Lannes, S. C. S. (2013b). Yield, nutritional quality, and thermaloxidative stability of Brazil nut oil (Bertolletia excelsa H.B.K) obtained by supercritical extraction. Journal of Food Engineering, 117(4), 499-504. http://dx.doi.org/10.1016/j.jfoodeng.2013.01.013.

Santos, O. V., Corrêa, N. C. F., Soares, F. A. S. M., Gioielli, L. A., Costa, C. E. F., \& Lannes, S. C. S. (2012). Chemical evaluation and thermal behavior of Brazil nut obtained by different. Food Research International, 47(2), 253-258. http://dx.doi.org/10.1016/j.foodres.2011.06.038.

Santos, R. C., Melo, A. A. Fo., Chagas, E. A., Takahashi, J. A., Montero, I. F., Holanda, L. C., Ribeiro, P. R. E., Santos, G. F. S., \& Melo, A. C. G. R. (2017). Chemical characterization of oils and fats from amazonian fruits by ${ }^{1} \mathrm{H}$ NMR. Food Chemistry. In press.

Siguemoto, E. S. (2013). Composição nutricional e propriedades funcionais do murici (Byrsonima crassifólia) e da moringa (Moringa oleífera) (Dissertação de mestrado). Universidade de São Paulo, São Paulo.

Souza, D. F. S., Antoniassi, R., Freitas, S. C., \& Bizzo, H. R. (2007). Estabilidade oxidativa dos óleos de macadâmia e de pistache. Boletim do Centro de Pesquisa e Processamento de Alimentos, 25(1), 141-156. http://dx.doi.org/10.5380/cep.v25i1.8402.

Souza, V. R., Pereira, P. A. P., Queiroz, F., Borges, S. V., \& Carneiro, J. D. S. (2012). Determination of bioactive compounds, antioxidant activity and chemical composition of Cerrado Brazilian fruits. Food Chemistry, 134(1), 381-386. http://dx.doi.org/10.1016/j. foodchem.2012.02.191. 
Sovová, H. (2012). Steps of supercritical fluid extraction of natural products and their characteristic times. The Journal of Supercritical Fluids, 66, 73-79. http://dx.doi.org/10.1016/j.supflu.2011.11.004.

Sovová, H., Galushko, A. A., Stateva, R. P., Rochova, K., Sajfrtova, M., \& Bartlova, M. (2010). Supercritical fluid extraction of minor components of vegetable oils: $\beta$-sitosterol. Journal of Food Engineering, 101(2), 201-209. http://dx.doi.org/10.1016/j.jfoodeng.2010.07.002.

Tan, C. P., Che Man, Y. B., Selamat, J., \& Yusoff, M. S. A. (2002). Comparative studies of oxidative stability of edible oils by differential scanning calorimetry and oxidative stability index methods. Food Chemistry, 76(3), 385-389. http://dx.doi.org/10.1016/S0308-8146(01)00272-2.

Teles, R. M. (2009). Caracterização química, avaliação térmica e atividade larvicida frente ao Aedes aegypti do óleo essencial da Aniba duckei
Kostermans (Tese de doutorado). Universidade Federal da Paraíba, João Pessoa.

Temelli, F. (2009). Perspectives on supercritical fluid processing of fats and oils. The Journal of Supercritical Fluids, 47(3), 583-590. http:// dx.doi.org/10.1016/j.supflu.2008.10.014.

Zambiazi, R. C., Przybylski, R., Zambiazi, M. W., \& Mendonça, C. B. (2007). Fatty acid composition of vegetable oils and fats. Boletim Centro de Pesquisa de Processamento de Alimentos, 25, 111-120.

Zivkovic, A. M., Telis, N., German, J. B., \& Hammock, B. D. (2011). Dietary omega-3 fatty acids aid in the modulation of inflammation and metabolic health. California Agriculture, 65(3), 106-111. http:// dx.doi.org/10.3733/ca.v065n03p106. PMid:24860193. 